\title{
Notes on the vocalizations of Black-backed Grosbeak (Pheucticus aureoventris)
}

Peter Boesman

In the following we briefly analyze and compare voice of the different races of Black-backed Grosbeak (Pheucticus aureoventris). We also try to quantify the extent of any vocal differences using the criteria proposed by Tobias et al. (2010), as a support for taxonomic review. We have made use of sound recordings available on-line from Xeno Canto (XC) and Macaulay Library (ML).

Our main interest is to compare yellow-throated race crissalis with all other (black-throatedraces. An overview of song illustrated with sonograms:
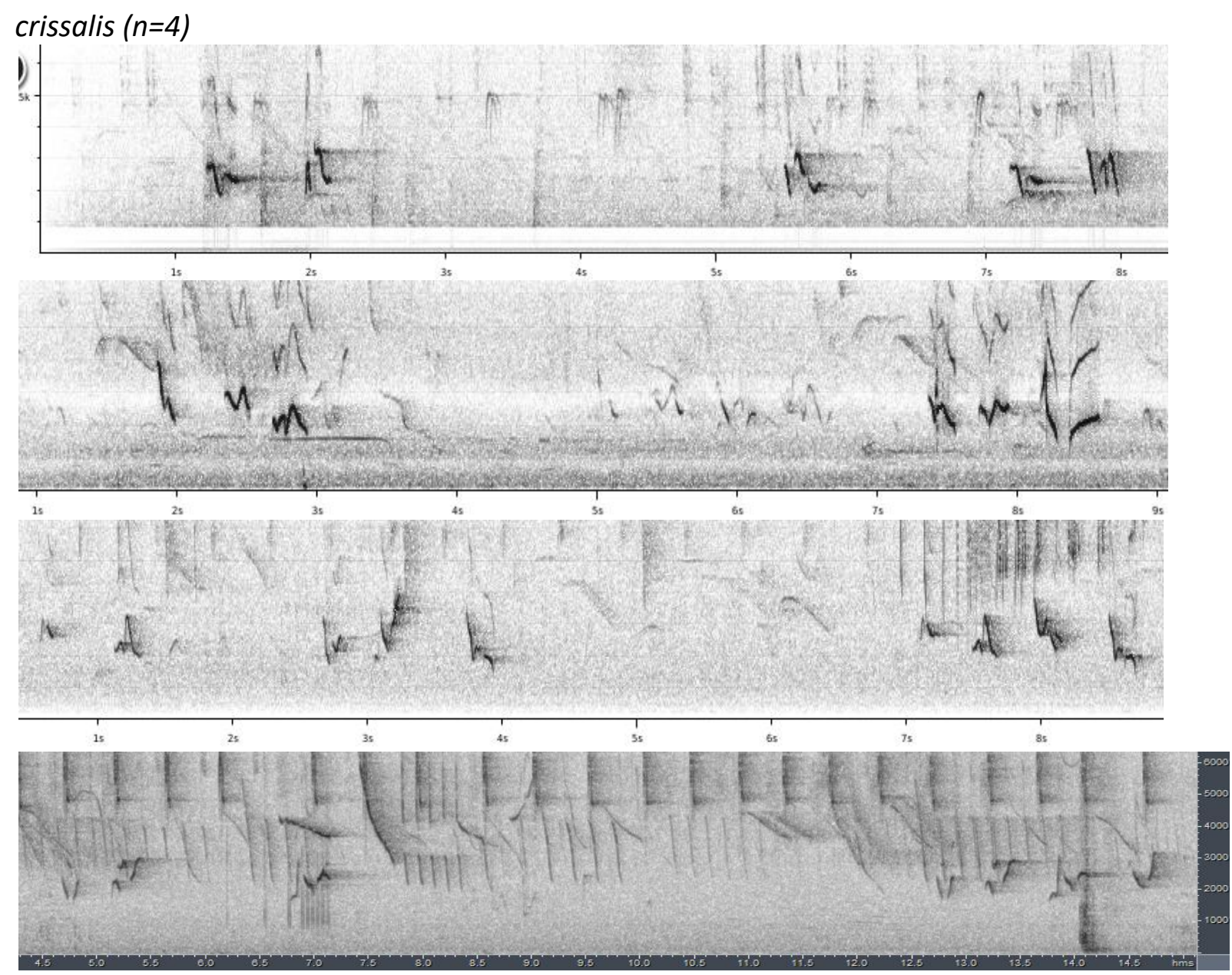
HANDBOOK OF THE

BIRDSPITEE WORLD ORNITHOLOGICAL NOTES

southern races

Peru

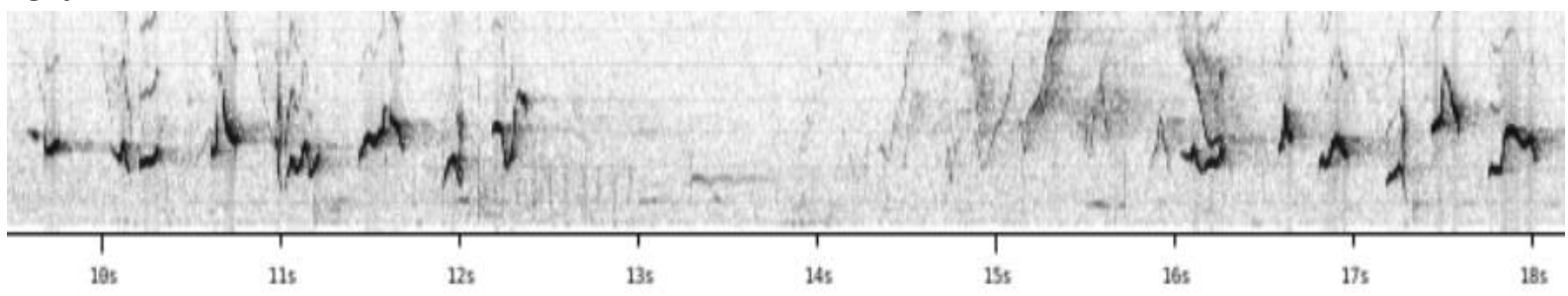

Bolivia

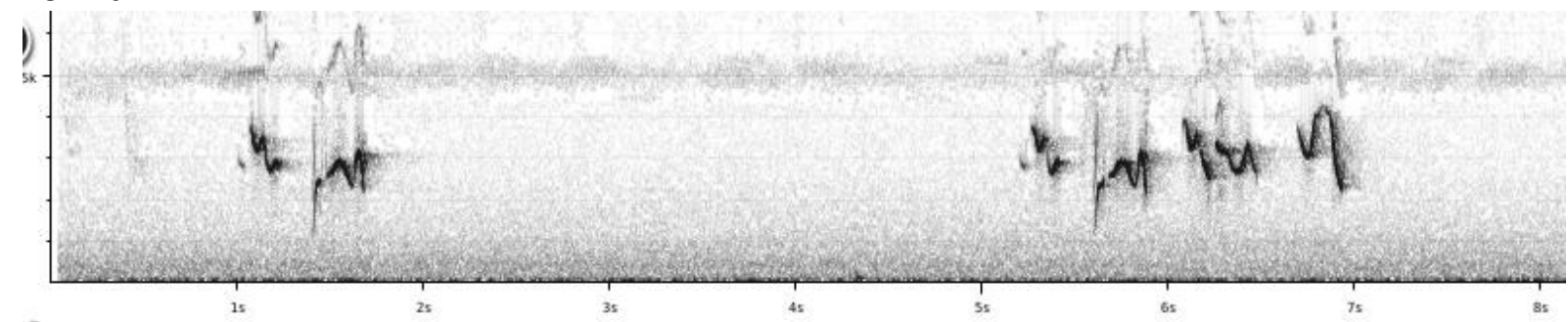

Argentina

$\sqrt{b} u^{k}$

tis $n J_{k}$

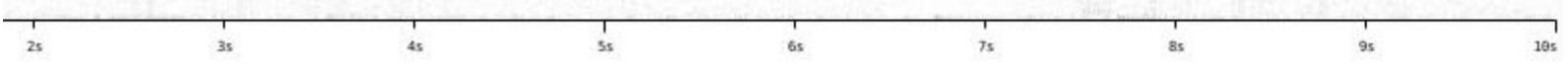

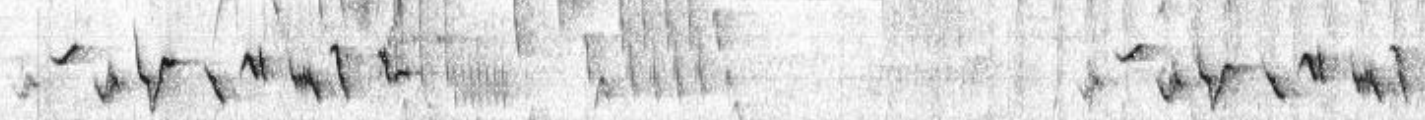

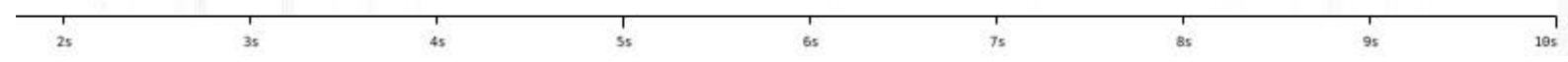

northern race (Colombia)
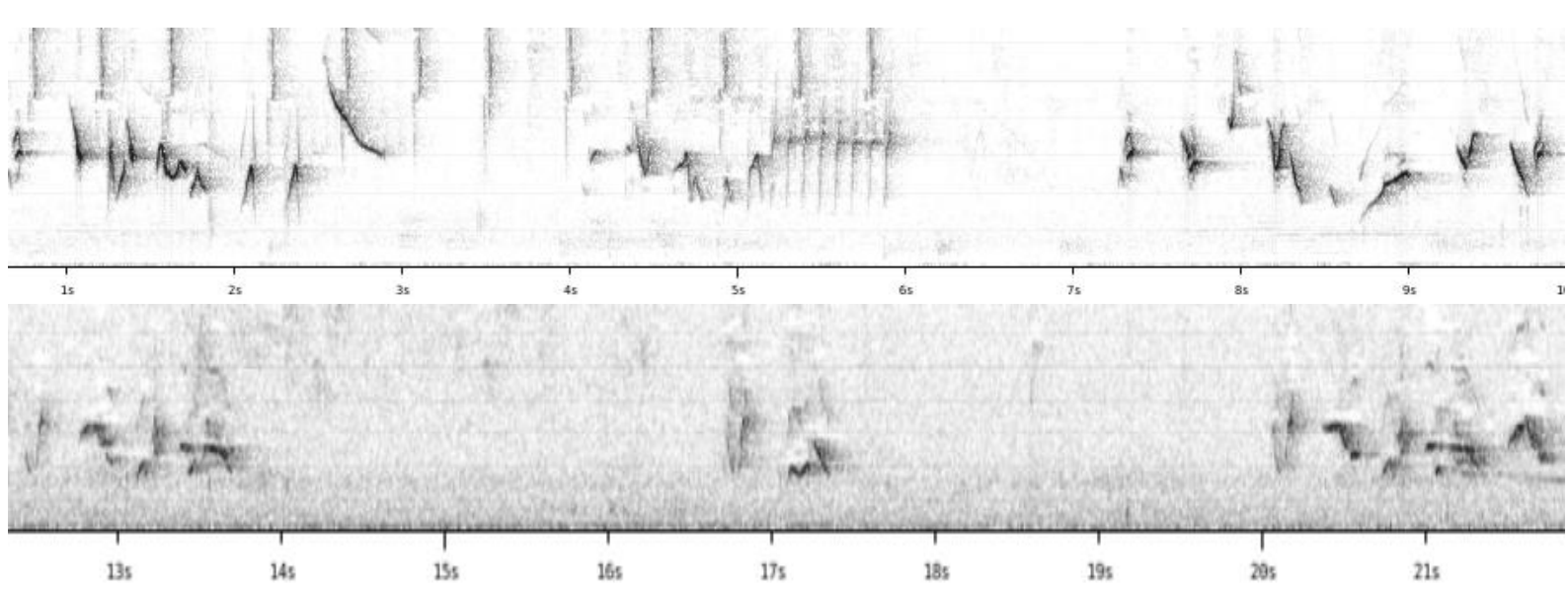

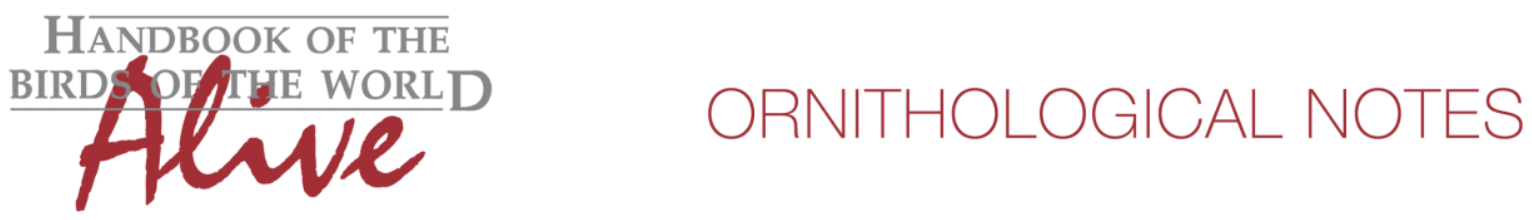

Song of all races is rather similar. crissalis seems to differ however in having very short song phrases of just a few notes (1-4 notes, duration 0.5-2s). Other races typically have somewhat longer song phrases with more notes (2-10 notes, duration $0.7-3 \mathrm{~s})$. Based on phrase length and number of notes, a total vocal score $1+1=2$ could be given.

This note was finalized on 29th June 2016, using sound recordings available on-line at that moment. We would like to thank in particular the sound recordists who placed their recordings for this species on XC, ML: Roger AhIman, Michael Anderson, Juan Areta, Nick Athanas, Peter Boesman, Paul Coopmans, Pablo Florez, José Giraldo, Mateo Hernandez, Niels Krabbe, Dan Lane, Bernabe Lopez-Lanus, Sjoerd Mayer, John V Moore, Gabriel Leite, Ted Parker, Mark Robbins, Fabrice Schmitt, Thomas Schulenberg, Glenn Seeholzer and Andrew Spencer.

\section{References}

Tobias, J.A., Seddon, N., Spottiswoode, C.N., Pilgrim, J.D., Fishpool, L.D.C. \& Collar, N.J. (2010). Quantitative criteria for species delimitation. Ibis 152(4): 724-746.

\section{Recommended citation}

Boesman, P. (2016). Notes on the vocalizations of Black-backed Grosbeak (Pheucticus aureoventris). HBW Alive Ornithological Note 383. In: Handbook of the Birds of the World Alive. Lynx Edicions, Barcelona. (retrieved from http://www.hbw.com/node/1252940 on 30 November 2016). 